\title{
STORY'S COMMENTARIES ON THE CONFLICT OF LAWS - ONE HUNDRED YEARS AFTER
}

$\mathrm{N}$ 1834 Story published the first edition of his Commentaries
on the Conflict of Lawes. ${ }^{1}$ With the publication of this work, it is now generally admitted, ${ }^{2}$ a new era began in the treatment of the subject. Italian, French, Belgian, Dutch, and German writers, among whom are to be found the greatest jurists of their time, had preceded Story in dealing with these questions. Bartolus, Dumoulin, D'Argentré, Rodenburg, John and Paul Voet, Huber, Froland, Boullenois, Bouhier, Cocceji, and Hert are a few of the names. $^{3}$ The writers lived in different ages and under different social and political conditions. Questions of the conflict of laws attracted the attention of the Italian jurists as early as the twelfth century. In northern Italy independent bodies of customary law had developed, especially in the municipalities, which prevailed over the more general law. In the absence of a particular provision of local law the common law, namely, Roman law, prevailed. The problems of the conflict of laws arose chiefly between the inhabitants of these municipalities. At first the law of the forum ${ }^{4}$ was applied to these disputes, but in the course of time more modern doctrines were developed. According to Magister

1 Joseph Story was born in Marblehead, Massachusetts, September r8, I779. He was graduated from Harvard College in 1798 and was admitted to the bar in I80r. In I8II, while Speaker of the Massachusetts House of Representatives, he was appointed to the Supreme Court of the United States. In I829 Story was elected Dane Professor of Law at Harvard University, which position he held, together with that of Associate Justice of the Supreme Court, until his death, September ro, I845.

Story was the author of many books. In his earlier years he compiled a work on Pleadne (1805); and edited Chitty on Biris and Notes (I809), Abbotr on ShIPpIng (r8ro), and Lawes on Pleadivg IN Assumpsit (I8II). As Dane Professor of Law he published works on BAtrMENTS (1832), the ConsTtTution of THE United States (I833), Conflict of Laws (I834), Equity Jurisprudence (I836), Equitx Pleading (I838), Agency (I839), Partnership (I84I), Bills of ExChange (r843), and Promissory Notes (I845).

2 Harrison, ON JURISPRUdence AND THE CONFLICT OF LAws (I919) IIg (published originally in the Fortnightly Review in 1878 and I879); GUTZWIIIER, DER Einfluss Savigny's (r923) III.

3 i Lainé, Interoduction au Droit International Privé (i888), II (I892).

4 See 2 NeUNEYeR, DIE GEMEINRECHTIICHE ENTWICKELUNG DES INTERNAtionalen Privat-und Strafrechts bis Bartolds (Igi6) i et seq. 
Aldricus, whom Professor Neumeyer regards as the founder of the science of private international law, the questions of the conflict of laws should be decided with reference to the law which is " the more powerful and useful ".5 Apparently the judge is to decide the case with reference to the law which shall bring about justice. The development of the conflict of laws reached its height in Italy in the fourteenth century through the genius of the greatest of all jurists of the middle ages - Bartolus of Sassoferrato (I3I4-I357). ${ }^{6}$

In France, however, difficulties in the conflict of laws arose between the inhabitants of the different provinces of a politically united kingdom. These questions seem to have come for decision before the Parliament of Paris and the Exchequer of Normandy as early as the thirteenth century. ${ }^{7}$ In the sixteenth century the subject of the conflict of laws was given a profound stimulus in France by the opposing views of Dumoulin ( $5_{500-1566)}$ and D'Argentré (I5I9-I590). Dumoulin placed the emphasis upon the "personal" statute (lex domicilii) whereas D'Argentré, influenced by the feudal notions prevailing in his native Brittany, urged the claims of the "territorial "law (lex rei sitae). Froland, Boullenois, and Bouhier developed D'Argentré's doctrine in the eighteenth century. ${ }^{8}$

The questions of the conflict of laws presented themselves under a still different aspect to the Dutch writers of the seventeenth century - Paul Voet (I6x9-I677), John Voet (I647-I7I4), and Ulricus Huber (I636-r694).9 In Italy they had been intermunicipal; in France, interprovincial; and in Holland they were looked upon for the first time as international. The Dutch provinces had just gained their independence. An extreme jealousy of their local rights existed between them. This fact, coupled with the growing commerce with foreign nations, caused them to regard the questions of the conflict of laws as arising between independ-

5 NEUMEYER, op. cit. supra note 4 , at 67 .

- Bartolus, Conflict of Laws (Beale's trans. IgI4).

7 See Metjers, Bijdrage tot de geschiedents van het internationaat Privaaten Strafrecht IN Frankrijk en de Nederlanden (Igr4); Nieure Bijdrage tot het ontstaan van het beginsel der Realiteit (I922) 3 TYJDSCHRIFT vOOR RECH.TSGESCHIEDENIS 6 I.

8 I LAINÉ, op. cit. supra note 3 , at 422.

- See Lorenzen, Huber's De Conflictu Legum in Wigmore's Cetebration LEGAL Essays (I919) I99. 
ent sovereignties. This led to the announcement of the doctrine of the "territoriality" of law in a more absolute sense than that proposed by D'Argentré.

The most important authors belonging to the early German school of the conflict of laws are Cocceji (I644-I7I9) and Hert (x652-I7ro), Cocceji being the first German who attempted to establish a general theory of the conflict of laws.

The continental writers referred to, living as they did in different ages, in different countries, and under different conditions, naturally reflected the ideas of their times. The Italian writers employed the scholastic method of their day. D'Argentré reflected the feudal notions of his native land. The Dutch writers were under the influence of their great compatriot Grotius. Not only did the different schools - the Italian, French, Dutch, and German - differ from each other, but there was considerable variation in the views of the writers belonging to each school. However, they employed a common method in dealing with the problems of the conflict of laws, which is commonly called the "statutory" method." They all started from the same premise. From first to last they examined the different laws - city laws in Italy, provincial laws in France, or the laws of the particular states in Germany - to ascertain whether they concerned persons, things, or acts. If it concerned persons, the enactment in question was known as a "personal" statute, governed by the law of the domicil. If it concerned things, it was known as a "real " statute, governed by the lex rei sitae. The term " mixed" statute was used by the different writers in various senses. Sometimes it had reference to acts and indicated that the lex loci controlled. Other writers employed it when the statute was deemed to refer partly to persons and partly to things. Whatever progress was made in the conflict of laws between the thirteenth and nineteenth centuries on the continent was the result of the theoretical discussions mentioned. The courts contributed little, if any, to the development of the subject. The statutory theory was accepted in the legislation of the eighteenth century by the Maximilian Code of Bavaria of $175^{11}$ and in part by the Prussian Code of $1794^{12}$

10 See I LAINÉ, op. cit. supra note 3 , at 45 et seq. $11 \mathrm{I}, 2, \S \mathrm{I}$.

12 Intr. $\S \S 22-42$; I Förster aNd Eccius, Preussisches Privatrecht (7th ed. 
The insufficiency of the statutory method is seen clearly from the arbitrary and contradictory conclusions to which it led. For example, the incapacity of a married woman to contract without the authorization of her husband, the incapacity of a minor to sell property, or the incapacity of a house-son to make a will, which would seem to affect the person, was held by some writers to relate to things, governed by the law of the situs. Again, if the law of the situs governs things because of the control the local law has over the property, why was movable property excepted from such rule and placed under the law of the domicil? Or, if the lex loci governs acts for the reason that the parties are temporary subjects of the state, why are they not so subject for all purposes? Why apply the lex domicilii with respect to persons? Assuredly, a particular law may affect at the same time persons and things or persons and acts. Any attempt, therefore, to solve the problems of the conflict of laws on the basis of a classification of laws into those affecting persons, things, or acts is bound to fail. The voluminous discussions of the writers on the conflict of laws prior - to Story are evidence of this fact. Story has referred to them in the following words: "Their works", he says, "abound with theoretical distinctions, which serve little other purpose than to provoke idle discussions, and with metaphysical subtleties, which perplex, if they do not confound, the inquirer." 13

Problems of the conflict of laws did not come before the English courts before the middle of the eighteenth century. Since that time they have presented themselves in ever increasing number, particularly in consequence of the enormous expansion in trade since the early part of the nineteenth century. Moreover, a considerable number of disputes involving the conflict of laws came also before the courts of the United States. The result was that upwards of 500 decisions by Anglo-American courts relating to this subject existed at the time Story wrote his Commentaries.

Characteristic of Anglo-American law has been its development by the courts and not by legal writers. In dealing with questions of the conflict of laws, however, the English courts, prior to Story,

I896) 53 et seq.; I Dernaurg, Preussisches Privatrecht (5th ed. I894) 5 I et seq.; I Koch, Altgemetnes Landrecht für die Preussischen Stanten (8th ed. I884) 38-54.

13 Story, Comomentaries on the Conflict of Laws (Ist ed. I834) \& II. 
relied to a large extent upon the discussions of continental writers, notably upon those of the Dutch school, whose territorial point of view appealed to the English judges. Huber's brief and concise commentary was most commonly cited. Very little had been done on the subject of the conflict of laws in England and America prior to Story. The most extensive English work on the subject was by Jabez Henry, who published in 1823 a work entitled The Judgment of the Court of Demerara in the Case of Odwin $v$. Forbes, to which was prefixed "A Treatise on the Difference Between Personal and Real Statutes", etc. ${ }^{14}$ In I830 and I83I, Fortunatus Dwarris published A General Treatise on Statutes containing a few pages relating to personal, real, and mixed statutes and certain elementary rules of the conflict of laws. ${ }^{15}$ In the United States Samuel Livermore had published, in I828 in New Orleans, a work entitled Dissertations on Questions Which Arise from the Contrariety of the Positive Laws of Different States and Nations, consisting of $\mathrm{I}^{2}$ pages. Volume 2 of Kent's Commentaries contained a discussion of foreign marriages, divorces, judgments, and assignments. ${ }^{16}$ None of these works, however, was a comprehensive exposition of Anglo-American law.

Story's work consisted of 557 pages. It was divided into 17 chapters entitled, respectively, Introductory Remarks (I-I8), General Maxims of International Jurisprudence (I9-38), National Domicil (39-49), Capacity of Persons (50-99), Marriage (I00-I8), Marriage - Incidents to (II9-67), Foreign Divorces (I68-92), Foreign Contracts (I93-307), Personal Property (308-57), Real Property (358-90), Wills and Testaments (39x402), Succession and Distribution (403-10), Foreign Guardianships and Administrations (4II-43), Jurisdiction and Remedies (444-90), Foreign Judgments (49I-5 5 ), Penal Laws and Offenses (516-22), Evidence and Proofs $(523-32)$. Leaving out of consideration for the present the general maxims discussed in Chapter II, we find in Story's chapter headings the classifications which have been followed substantially by all writers since. Instead of discussing the problem of the conflict of laws under the three traditional points of view of "personal", "real", and

14 Pp. I-86.

15 Part $\Pi$, at $647-5$.

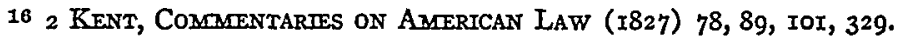


"mixed "statutes, Story grouped them with respect to the subject matter to which they related. The subject of domicil, which is covered in Ix pages, presents the general characteristics which it has today in the United States. This statement is subject, however, to one or two important qualifications. As regards the domicil of married women, no exceptions were recognized in the time of Story to the general rule that a wife's domicil follows that of the husband. ${ }^{17}$ In the matter of domicil of choice, Story held that a domicil so acquired would be retained until the acquisition of a new domicil facto et animo, except where a person abandons a domicil of choice with an intention to resume his native domicil, in which event the latter is reacquired in itinere, while he is on his way. ${ }^{18}$ This modification of the general rule finds no support in the decisions of the courts of the United States today.

Under the title Capacity of Persons, Story discusses the topics generally dealt with by the civilians under the heading of Status and Capacity. The discussion includes not only the power of minors, married women, prodigals, and lunatics to contract and to transfer property, and the "capacity" to marry, but also the subject of legitimacy and illegitimacy and legitimation by subsequent marriage. Contrary to the civil law writers, Story holds that the American law looks to the lex loci as regards capacity to contract ${ }^{19}$ and to marry, ${ }^{20}$ instead of to the law of the domicil. He justifies this rule on the grounds, (I) that the parties may be presumed to contract with reference to the law of the place where the contract was made and to be executed, and, (2) because of the certainty and simplicity in its application. ${ }^{21}$ In the matter of marriage, an exception would doubtless be recognized, according to Story, in the case of incest and polygamy. ${ }^{22}$ Story's views have become the established law in the United States. ${ }^{23}$

17 See STORY, op. cit. supra note $13, \S 49$.

18 Id. $\S 48$.

19 Id. $\S 76$.

20 Id. $\$ 89$.

21 Id. $\S 76$.

22 Id. \$89.

23 Some courts of the state of domicil have declined to recognize a foreign marriage, valid by the law of the place of celebration, which was entered into in evasion of the domiciliary law. See Beale, Laughlin, Guthrie, and Sandomire, Marriage and the Domicil (I93I) 44 HARv. L. REv. 5or. 
Differing from the continental writers, Story has no chapter devoted to the "formalities" of legal transactions. In continental literature the maxim locus regit actum denotes that the law of the place where the act is executed governs its formal requisites. Story uses it in a broader sense and applies it to the nature, obligation, and interpretation of contracts. ${ }^{24}$ The same rule governs the formal requisites of contracts, according to Story, even so far as they fall within the Statute of Frauds. ${ }^{25}$ The erroneous notion introduced later by Leroux v. Broven, ${ }^{26}$ that the Statute of Frauds is procedural, and thus governed by the lex fori, finds no support in Story's Commentaries. As regards dispositions of land, inter vivos and by will, the law of the situs was held by Story to govern the formal requisites, ${ }^{27}$ a doctrine early fixed in Anglo-American law. With respect to wills of personal property Story approved the general rule laid down by the courts that the law of domicil at the time of death controlled even in the matter of formal requisites. $^{28}$ The rigidity of the Anglo-American law led later to a modification of this rule by statute.

Story favors the view, upon principles of public policy, that marriage should be governed by the law of the place of celebration, even in cases of evasion, "with a view to prevent the disastrous consequences to the issues of such a marriage ". ${ }^{29}$ The incidents to marriage, especially the effect of marriage upon the property of the spouses, are stated by Story substantially as they would be today. As regards movables owned at the time of the marriage, he would apply the law of their matrimonial domicil, that is, the law of the state where they expected to make their home. Story says that the American decisions in support of the doctrine could be justified on the analogy to contracts by assuming a tacit matrimonial contract, "if it can be so treated", which would be governed by the law of the place of performance, or, if governed by the municipal law, without reference to any tacit contract, Story felt that the application of the law of the future domicil was "equally capable of a solid vindication".80

In connection with the subject of divorce Story points out the

24 STORY, op. cit. supra note $13, \S 263$.

25 Id. $\S 262$.

26 I2 C. B. 8or (I852).

27 STORY, op. cit. supra note $\mathrm{r}_{3}, \S \S 435,475$.
28 Id. $\$ 636$.

29 Id. $\S$ I23.

30 Id. § Igg. 
difficult problems arising on the continent and between England and Scotland because of the divergency in the local legislation. Less than four pages are devoted to the law of the United States. ${ }^{31}$ Divorces, while not unknown in this country at the time, were not as easily obtained as they are today. The infrequency of foreign divorces is accounted for partly by the fact that married women at the time could not establish separate domicils. At the time of Story it was already the established law that the grounds for divorce were governed by the lex fori, and that a divorce obtained in a state in which both spouses had acquired a bona fide domicil would be recognized, even by the courts of the state in which the parties had their domicil at the time of the alleged offense, although there was no cause for divorce under the law of such state.

The subject of contracts is developed at length by Story. ${ }^{32} \mathrm{He}$ deals with contracts in general and also with special classes of contracts, such as contracts relating to land, contracts for the purchase or sale of goods, and bills and notes. "Generally speaking," says Story, "the validity of a contract is to be decided by the law of the place, where it is made." 33 " Where the contract is either expressly or tacitly to be performed in any other place, there the general rule is, in conformity to the presumed intention of the parties, that the contract, as to its validity, nature, obligation, and interpretation, is to be governed by the law of the place of performance. This would seem to be a result of natural justice; and the Roman law has (as we have seen) adopted it as a maxim." ${ }^{34}$ Story cites in support of the proposition Voet, Huber, and Boullenois and states that it has the general consent of foreign jurists. He cites in support also the dictum of Lord Mansfield in Robinson v. Bland, ${ }^{35}$ Kent's Commentaries, and seven American cases de-

31 STORY, op. cit. supra note I3, §§ 228-30.

33 Id. $\$ 242$.

32 Id. $\$ \S 23 \mathrm{I}-373$.

$34 I d . \$ 280$.

352 Burr. I077, ro78 (K. B. I760). It has been charged that the law of the place of performance is inconsistent with the principles of the common law, being an importation from the civil law. Beale, What Law Governs the Validity of a Contract (I909) 23 HaRv. L. REv. I, 6 et seq. Such a charge can be supported, however, only if a preconceived view is taken of what constitutes the common law. Moreover, in the light of its long pedigree, both in England and the United States, it would seem to be as much entitled to recognition as a legitimate offspring of the common law as any other doctrine of the conflict of laws, which may have been first adopted on the continent. 
cided by the United States Supreme Court, by a federal circuit court, and by the courts of New York and Massachusetts. ${ }^{36}$ Story's view regarding the law governing the validity of contracts where the place of performance and that of the place of making do not coincide has been followed by a large number of cases in the United States, but it has been rejected by the American Law Institute. ${ }^{37}$

Movables at the time of Story were regarded everywhere as subject to the law of the owner's domicil. Mobilia sequnntur personam was an adage which expressed the rule in the conflict of laws since the early days when the question was discussed. "It has so general a sanction among all civilized nations ", says Story, " that it may be treated as a part of the jus gentium." "38 Story admits, however, that the legislation of the place where the property is situated, having actual control over the res, has the power to dispose of it in accordance with its law, but queries how far courts of justice ought, upon their own authority, to interpose such a limitation, independently of legislation, "since the doctrine, which it unfolds, aims a direct blow at the soundness of the policy, on which the general rule, that personal property has no locality, is itself founded." 39 It was only in the second half of the nineteenth century that the importance of legal transactions relating to personal property produced a fundamental change in the point of view which led to the adoption of the rule that the law of the situs should control rights in movables as well as in immovables.

That rights in immovables were subject to the law of the situs has been established in Anglo-American law in a much more absolute sense than it ever was on the continent. Thus, it had become fixed law in the time of Story that it controlled in the matter of conveyancing, both the capacity of the parties, the formalities with which the deed must be executed, as well as the extent of the interest to be conveyed. ${ }^{40}$ Likewise, the effect of marriage upon immovables, owned by the spouses at the time of marriage or subsequently acquired, and any other interest claimed in im-

\footnotetext{
36 STORY, op. cit. supra note 13, § 28I, n.7.

37 RestateMent, CONFLict OF Laws (1934) \& 332.

s8 STORY, op. cit. supra note I3, $\$ 380$.

39 Id. $\S 390$.

40 Id. $\$ \S 364,428-3 I, 445$.
} 
movable property by operation of law could be determined only with reference to the lex rei sitae. ${ }^{41}$

In the law of wills and succession the same principle was recognized, so that immovables would pass in case of intestacy to the heirs specified by the law of the situs. Wills disposing of immovable property had to conform to the law of the situs, both as to the capacity of the testator, the formalities with which the will had to be executed, and the validity of the will in any other respect. ${ }^{42}$ Movable property, on the other hand, would be distributed in case of intestacy in accordance with the law of the decedent's domicil at the time of his death. This law controlled also the formalities of such wills and their validity in other respects. ${ }^{48}$ These characteristic features of the common law, settled already in the time of Story, have been modified since his day only, by statute, as regards the formal execution of wills, by liberalizing the rules relating thereto. On the continent, owing to the doctrine of universal succession, both movable and immovable property is frequently subject to the same law.

In the settlement of decedents' estates, likewise, a wide distinction is made between movable and immovable property. ${ }^{44}$ The views announced by Story in this regard, as well as his observations relating to foreign guardianships, have remained the basic principles of our law.

In the chapter on Jurisdiction and Remedies, Story outlines the fundamental rules of jurisdiction which characterize AngloAmerican law and differ widely from the rules on the continent. Most important of these is the foundation of jurisdiction in personam upon mere personal service. Such jurisdiction is claimed not only as to citizens, but also as to foreigners who happen to be momentarily in the state, without reference to the place where the contract was made or to be performed, where the tort was committed or the like. With respect to jurisdiction over citizens domiciled abroad, "the extent of jurisdiction, which may be lawfully exercised over them in personam, is not so clear by acknowledged principles." ${ }^{45}$ So far as such exercise of jurisdiction comes before the courts of the state in which such citizens are domiciled, "the

41 STORY, op. cit. supra note I3, § 448.

42 Id. $\$ 474$.

43 Id. $\S \S 465-68$.
44 Id. §§ 509 et seq.

$45 I d . \S 540$. 
duty of recognising and enforcing such claim of sovereignty, is neither clear, nor generally admitted. The most, that can be said, is, that it may be admitted ex comitate gentium; but it may also be denied ex justitiâ gentium, wherever it is deemed injurious to the interests of foreign nations, or subversive of their policy or institutions." 46

At the time Story wrote, the Fourteenth Amendment to the Constitution had not been adopted, and the carrying on of interstate business by corporations had not taken the developments of today. There was no special reason, therefore, for a discussion of the problem of jurisdiction over foreign corporations and the abuses of imported litigation.

Regarding the Statute of Limitations, Story approves the view held by Huber, Paul Voet, and others, that it concerns the remedy and is thus subject to the lex fori. He takes issue with those foreign jurists who regard the Statute of Limitations as affecting the substantive rights of the parties, arguing, (I) that foreigners are not entitled to crowd the tribunals of any nation with suits of their own, and, (2) "as little right can they have to insist, that the times, provided by the laws of their country, shall supersede those of the nation, in which they have chosen to litigate their controversies." ${ }^{47}$ Story suggests, however, a possible distinction where the Statute of Limitations of a particular country not only extinguishes the right of action, " but the claim or title itself, ipso facto", and the parties are resident within the jurisdiction during the entire period. Under such circumstances title to personal property held adversely has been recognized, and Story intimates, though he does not state so expressly, that a similar doctrine might be justifiable in cases where a debt is extinguished by reason of the expiration of the Statute of Limitations. ${ }^{48}$

Judgments of foreign countries at the time of Story were regarded both in England and the United States merely as prima facie evidence to sustain the action, and to be deemed right until the contrary is established. ${ }^{49}$ Since that date they have been deemed conclusive in England and in most of the states of this country in which the question has arisen.

46 Ibid. Cf. Restatement, Confutct of Laws (1934) $\$ \$ 47(2), 80$.

47 STORY, op. cit. supra note $\mathrm{I}_{3}, \S 578$.

$48 I d . \S 582$.

49 Id. $\$ 603$. 
The subject of crimes in its international aspects is dealt with to a very limited extent. ${ }^{50}$ Under the chapter heading of Penal Laws and Offenses Story states that the common law "considers crimes as altogether local, and cognizable and punishable exclusively in the country, where they are committed." 51 For the same reason a disability imposed for conviction of crime has no extraterritorial effect. Regarding the extradition of criminals, Story agrees with the view that a sovereign is not bound to render up fugitive criminals from other countries. The enforcement of "penal" laws in disputes between private individuals is not alluded to.

In the final chapter, entitled Evidence and Proofs, Story lays down the established doctrine of Anglo-American law that courts will not take judicial notice of the laws of a foreign country, but that they must be proved as facts. ${ }^{52}$ He also deals with what he calls a "most embarrassing, and as yet (in a great measure) unsettled class of questions" ${ }_{53}$ relating to the mode of proving foreign contracts, instruments, and other acts. Story points out that the competency of witnesses is governed in the common law by the lex fori, but intimates that where the only witness to a contract is incompetent, on account of interest, by the common law, but competent by the law of the place where the contract was made, his testimony might be admissible. ${ }^{54}$ So far as the Statute of Frauds is involved or the requirement of a stamp, the instrument not being admissible in evidence unless it is properly stamped, Story holds that " in all these cases the proper proof would doubtless be given in conformity with the local law." ${ }^{55}$

If we compare this summary of Anglo-American law on the subject of the conflict of laws as it was one hundred years ago with the law of today, we find that it has changed only in minor respects. Its fundamental views and conceptions are the same. Story first formulated them, and where they were not firmly established at the time, they became so, thanks to the great esteem in which his work was held.

A second and considerably enlarged edition of Story's Com-

50 STORY, op. cit. supra note $13, \S \S 6 I 9-28$.

53 Ibid.

51 Id. $\$ 620$.

54 Id. $\$ 635$.

52 Id. $\$ 637$.

55 Id. $\$ \$ 262,631$. Cf. Restatement, Conflict of Laws (r934) \$\$ 598, 602. 
mentaries appeared in $184 \mathrm{I}$, and a third edition, containing the author's last revisions, was published in 1846 , after his death. By this time the size of the book had grown to I068 pages. The fourth edition was published by $\mathrm{E}$. H. Bennett, in $I 852$; the fifth edition by the same editor, in 1857 ; a sixth edition by Isaac $F$. Redfield, in $\mathrm{I} 865$; a seventh edition by $\mathrm{E}$. H. Bennett, in 1872 ; and an eighth edition by Melville M. Bigelow, in I883.

Characteristic of Story's work is his detailed consideration of the views of continental writers, from which he quotes copiously. Story says that in the preparation of his Commentaries he has availed himself chiefly of the writings of Rodenburg, the Voets (father and son), Froland, Boullenois, Bouhier, and Huber " as embracing the most satisfactory illustrations of the leading doctrines ".56 Most references are to Boullenois, but great reliance is placed upon Huber, of whom he writes, "Some attempts have been made, but without success, to undervalue the authority of Huberus. . . . It is not, however, a slight recommendation of his works, that hitherto he had possessed an undisputed preference on this subject over other continental jurists, as well in England as in America." ${ }^{57}$ Of the German writers Story consulted only those who wrote in Latin; many references are to be found to Hert's De Collisione Legum.

At the time of their publication Story's Commentaries on the Conflict of Lawes made a profound impression. Not only did they become the authoritative work upon the subject in the United States, but they were held in very high regard in England. Burge said of Story's Commentaries in I838, "His Treatise on the conflict of laws . . . is cited by English judges with the high commendation it so justly merits, . . . ." 58 Frederic Harrison said in I879 that "from the date of its appearance hardly a single case on this subject in America or in England, and perhaps few on the Continent, have ever been decided without some reference to this learned book." 59 Dicey, in I9I 2, emphasized Story's "powerful common sense and extensive legal learning", ${ }^{60}$ saying also, "The

56 STORY, op. cit. supra note I3, § II, n.2.

57 Id. $\S 3$ I.

58 I Burge, Comanentaries on Colonial and Foretgn Laws (I838) xi.

59 Harrison, loc. cit. supra note 2.

60 (IgI2) 28 L. Q. REv. 34I, 342. 
great merits of Story must be acknowledged by every one who can recognize the strength and solidity of good legal thinking." ${ }^{61}$ In France, Foelix became an enthusiastic follower. He says, in $\mathrm{I} 843$, "This result, to which we have been led by our researches and meditations, we find confirmed and developed in the learned work of Story. . . . We have not hesitated to adopt this doctrine, and we have followed it throughout our work." ${ }^{2}$ For half a century Foelix's treatise was the standard work on the conflict of laws in France and as such had a considerable influence upon the French decisions. In Germany, Professor Mittermaier reviewed, in I835, Story's Commentaries at length in the Kritische Zeitschrift fïr Rechtswissenschaft und Gesetzgebung des Auslandes, ${ }^{63}$ in which he gave high praise to the American author. He dwells upon Story's " rare practical sense ", ${ }^{64}$ combined with a " strict scientific training". ${ }^{65}$ Half a century later Bar speaks of Story's "wondrous power of comparison " ${ }^{66}$ the " masterly fashion " ${ }^{67}$ in which he sets forth the Anglo-American decisions, and the "great subtlety" with which he criticizes "the details of the grounds of judgment". ${ }^{88}$ Savigny made constant use of Story's Commentaries, of which he says: "A remarkable picture of this imperfect but hopeful state of things is presented in the excellent work of STORY, which is also extremely useful, as a rich collection of materials for every inquirer." ${ }^{69}$

No work of importance had appeared in any country on the subject of the conflict of laws since the publication by Boullenois of his Dissertations sur Les Questions qui naissent de la contrariété des loix et des coutumes (I732) and his Traité de la Personnalité et de la Réalité des loix, coutumes, ou statuts ( I766). All the writers preceding Story had followed the statutory method, seeking to arrive at the solution of the problems of the conflict

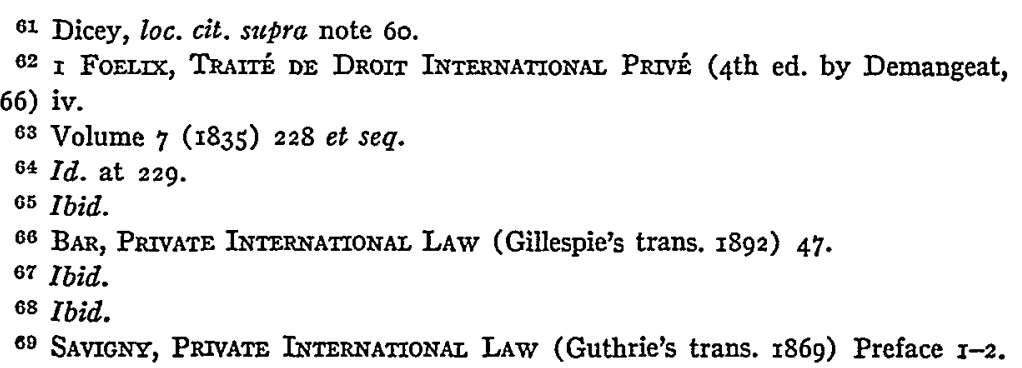


of laws by a classification of all laws into "personal", "real", and "mixed", a method which had proven barren of any definite results. Story likewise expresses some of the old ideas, but with him they constitute merely the veneer or "shell", "but not the groundwork of his treatise. The substance of the Commentaries was based upon the decisions of Anglo-American courts. This constituted a new method and a complete break with that of the statutory school, the fetters of which Story helped to destroy in Europe.

At the time of their publication, in I834, Story's Commentaries were without question the most remarkable and outstanding work on the conflict of laws which had appeared since the thirteenth century in any country and in any language. One hundred years have elapsed since then, during which, owing to the large increase in international trade and intercourse, the subject of the conflict of laws has gained greatly in importance. In the interval a large number of treatises on the subject have been written in many countries by some of the greatest jurists. Learned societies have been formed to study the problems of the conflict of laws. Legal periodicals have been established exclusively for the same purpose. International conventions have sought to unify the rules with reference to some of the most important topics. The United States this very year has witnessed the completion of a vast undertaking, the Restatement of the Conflict of Laws by the American Law Institute. During this century great changes have taken place also in the political or juridical conditions of the different countries. In France, Italy, and Germany, the law has been unified, so that before the World War the questions of the conflict of laws could arise in those countries only between such countries and foreign nations. As a result the interprovincial or interstate side of the conflict of laws largely disappeared. But, with the dislocation of physical boundaries as a result of the war, interprovincial law has for the time being gained renewed importance. ${ }^{71}$ In the United States the Federal Government has been forced since the time of Story to exercise powers formerly exercised by the states, notably in the field of interstate transportation, so as to prevent questions of the conflict of laws from arising in this field

70 GUTZWILLE, op. cit. supra note 2, at III.

71 For example, in France, Poland, and Czecho-Slovakia. 
between the states of this country. The due process clause of the Fourteenth Amendment to the Federal Constitution has played an ever increasing rôle in limiting the freedom and power of the state courts and legislatures. In the light of all these developments, what place may Story's Commentaries on the Conflict of Laws be said to occupy today?

So far as Anglo-American law is concerned, important works on the subject of the conflict of laws have since been written in England by Westlake, Dicey, and Foote, which have taken Story's place as authoritative statements of the modern English law. In the United States no similar works have appeared. The only larger treatise on the subject is by Wharton, ${ }^{72}$ which made no distinct contribution to the subject. A century after their original publication, Story's Commentaries continue to be freely cited by the courts of the United States.

On the continent many eminent jurists have been attracted by the conflict of laws since the time of Story. The following are among the familiar names ${ }^{73}$ in France, Foelix, Despagnet, Weiss, Lainé, Audinet, Surville \& Arthuys, Pillet, Vareilles-Sommières, Bartin, Niboyet, Arminjon, Valery; in Belgium, Laurent, Rolin, Poullet; in Germany, Savigny, Bar, Niemeyer, Zitelmann, Kahn, Neumeyer, Frankenstein, Gutzwiller, Lewald, Melchior, Nussbaum, Wolff; in Holland, Asser, Jitta, Kosters; in Italy, Mancini, Fiore, Lomonaco, Catellani, Fusinato, Contuzzi, Diena, Anzilotti, Cavaglieri, Pacchioni, Ago; in Austria, Walker; in Switzerland, Meili, Roguin, Brocher. Some of these writers have set forth the law of the particular country to which they belonged. Most of them, however, wrote theoretical works dealing with the fundamental principles of the subject. Starting with a priori premises, for which the authors claimed universal validity, they erected thereon, largely by deductive processes, their "systems" of the conflict of laws. This is not the place to indicate differences in the points of view maintained by the authors nor even to attempt a classification of their doctrines. ${ }^{74}$ Of importance in this study is to ascertain how they compare with Story as regards their influ-

\footnotetext{
72 A monumental treatise by Professor Beale is to be published in the near future.

${ }^{73}$ The authors appear more or less in chronological order, according to the dates of their publications.

74 See Beale, Treatise on the Conflict of Laws (Igi6) 62-II3.
} 
ence upon the conflict of laws. Of the nineteenth century writers two names stand out in this respect above the rest, and these are Savigny and Mancini.

Savigny, known everywhere as the great German Romanist and the leading figure of the modern historical school, published five years after the appearance of Story's Commentaries, the eighth volume of his great treatise on modern Roman law, dealing with the application of law from the standpoint of time and place. ${ }^{75}$ Savigny looked for a scientific foundation of the rules of the conflict of laws, which would enable them to develop on a universal basis, unhampered by the restricting infiuences of any particular local system of law. This scientific basis Savigny found to rest in the modern world upon the interdependence of sovereign states. According to Savigny, the problem of the conflict of laws does not involve the question whether the statutes of a particular state or country affect persons, things, or acts (as was the view of the statutory jurists), nor is it primarily a question of the limits of the power of a given legislator. In his estimation the question may be stated thus: "To ascertain for every legal relation . . . that law to which, in its proper nature, it belongs or is subject." "76 This, he said, may be regarded as "a friendly concession among sovereign states", but " this suffrance must not be regarded as the result of mere generosity or arbitrary will, which would imply that it was also uncertain and temporary", but as "the proper and progressive development of law" ${ }^{77}$ The judge must apply the law of the state or country to which the legal situation before the court belongs, called by Savigny the "seat" of the obligation.

Savigny's treatise met with a most enthusiastic reception, not only in Germany and on the continent in general, but likewise in England, where it has been referred to, until the appearance of the modern English works by Westlake, Dicey, and Foote, more often than any other work except that of Story. Savigny did not try to find a direct solution for the manifold problems in the conflict of laws, but he sought to find a method which would furnish a key to their solution. The method that he gave to the world was

75 The full title of the work in English is Private Internatronar LAw - A Treatise on tHe Conflict of Laws, and tHe Limits of thetr Operation IN RESPECT OF PIACE AND TAME.

76 SAvigNY, op. cit. supra note 69 , at 27 . 77 Id. at 28 . 
hailed as the veritable beginning of the modern science of the conflict of laws, and with it the work of the statutory writers lost on the continent all further influence. Story's Commentaries has created a new epoch in the history of the conflict of laws, but his work was a practical one, based on the experience of AngloAmerican courts. Conditions on the continent were different. The courts did not occupy there the prestige held by them in England, the result being that the continental law was developed by the jurists rather than by the courts. Story's mode of approach was, therefore, foreign to that in vogue on the continent. Moreover, the Anglo-American conflict of laws had grown up along peculiar channels, influenced by feudalistic conceptions and insular notions of the common law, which were antagonistic to those recognized in continental Europe. While the rich storehouse of English and American decisions and the judicial appraisal thereof by a learned and practical-minded judge could not help being appreciated and was in the nature of things drawn upon, Savigny's theoretical work was more in harmony with their mode of thinking. Since its appearance and until the end of the nineteenth century, Savigny's treatise on the conflict of laws may be said to have dominated continental thinking on the subject.

The third leading figure of the nineteenth century in the field of the conflict of laws is Mancini. This great Italian statesman occupies a position quite different from that of either Story or Savigny. He wrote neither a great practical work on the conflict of laws of Italy, nor did he launch into the world an epoch-making theoretical treatise. His fame goes back to a lecture delivered by him on January 22, I85I, at the University of Turin on the subject of "Nationality as the Basis of International Law".78 In this lecture Mancini propounded a new theory of law, to the effect that law is essentially personal instead of territorial. It is made for a people and not for a territory - for a people whose common consciousness of nationality is derived from the landscape of the country in which they were born, from race, speech, custom, history, law, and religion. Law is territorial only insofar as it is a matter of public order. In the system of Mancini the notion of public policy no longer intervenes by way of exception in the con-

78 Delia Naztonalità come Fondamento det Diritto delli Gentr. 
flict of laws as a limitation upon the application of foreign law, as it still does with Savigny. It constitutes one of the two fundamental principles upon which the rules of the conflict of laws rest. If a given provision of a local law is one of public order, it is territorial and applicable to all within the territory, without reference to their nationality. If it does not fall within this category, it is personal, and the lex patriae controls. The conclusion last stated was modified, however, by a third fundamental principle, relating to the autonomy of the parties and the idea of liberty, according to which the law chosen by the parties will control, so far as they are free to choose the law.

The new doctrine announced by Mancini, so contrary to that of Story and Savigny, came at a time of national aspirations and for that reason found a welcome response, not only in Italy but elsewhere. The principle of nationality was adopted by the Italian Civil Code, of $\mathrm{x} 865$, as the law governing capacity, status, and domestic relations, the rights of succession upon death, and to some extent the law governing contracts. In the legislation of other countries the lex patriae displaced the lex domicilii as regards capacity and status and in other respects. Mancini's views exerted also great influence upon the courts of continental Europe belonging to the Latin group, especially in the matter of "ordre public". Every legislation dealing with the conflict of laws in Europe since the time of Mancini has made nationality the basis of the personal law in its system of the conflict of laws. It is only in the most recent times that a certain reaction has set in among the continental writers against the views advocated by Mancini, it being recognized today that the law of domicil has a legitimate place alongside that of the lex patriae.

In the twentieth century another person has arisen who deserves to be mentioned in connection with Story, Savigny, and Mancini, as one of the great figures in the field of the conflict of laws. This is Dr. Antonio Bustamante, of Havana, Cuba. A distinguished jurist, his title to recognition among the great personalities in the field of the conflict of laws rests upon his authorship of the Pan-American Code of Private International Law, ${ }^{79}$ which

70 Bustamante, Sixth Internattonat Conference of American States, Havana (r928) Final Act, 20 et seq.; see also Bustamante, Derecho InTernacronal Privado ( 3 vols. I93i). 
was adopted at the Sixth Pan-American Conference at Havana in I928, and which has been ratified by many of the Latin-American countries ${ }^{80}$ The scope of the conflict of laws, according to Bustamante, is a two-fold one. It should indicate what foreign laws should be recognized as operative within a given state or country, and in addition it should set out the limits within which, from an international point of view, the legislation of such state or country should be confined. Similarly to the classification suggested by Mancini's doctrine, Bustamante would divide all laws into three classes: (I) those applying to persons by reason of their domicil or nationality and following them even when they go to another country. These he calls personal, or of an internal public order. (2) Those binding alike upon all persons residing within the territory, whether or not they are nationals. These he calls territorial, local, or of an international public order. (3) Those applying only to the expression, interpretation, or presumption of the will of the parties, or of one of them. These he calls voluntary or of a private order. The difficulty with this mode of approach is that it furnishes no solution whenever the countries with which the juridical situation is connected fail to classify their laws in the same manner..$^{81}$ It also throws upon the judge of the forum the duty of classifying laws of a foreign country in accordance with the three-fold division above suggested, a task which he is scarcely able to undertake successfully.

Story's general theory of the conflict of laws is presented in the first two chapters of his Commentaries. According to Story, the laws of a country operate proprio vigore only within the limits of their territory. Whatever extraterritorial power they have results from their voluntary recognition, on grounds of comity, by the other states or countries. In thus attributing territorial force to law, Story follows the general maxims formulated by Huber. Story says: "The laws of every state affect, and bind directly all

80 No agreement could be reached at the Conference regarding whether the law of domicil or that of nationality should determine the personal law. The Convention allows each ratifying state to choose between the two.

81 For example, if two foreigners enter into a legal transaction in Cuba and the local Cuban law applicable to the matter is regarded as personal, that is, as falling within the first class, no solution is furnished by the Pan-American Code if the national law of the parties should deem it territorial, that is, as falling within the second class. 
property, whether real or personal, within its territory." 82 And " no state or nation can, by its laws, directly affect, or bind property out of its own territory, or persons not resident therein, ...." " "Whatever force and obligation the laws of one country have in another, depends solely upon the laws, and municipal regulations of the latter, that is to say, upon its own proper jurisprudence and polity, and upon its own express or tacit consent." 84

Most continental writers have been severely critical of Story's theory of "comity". As used by the Dutch writers the term "comity" had a political connotation, which appears to leave the application of foreign law to the discretion of the courts, instead of basing it upon a duty to do justice. Story stated, however, expressly, that it rested upon "a sort of moral necessity to do justice". ${ }^{85}$ Nevertheless, no amount of explanation will cause the theory of "comity" to be acceptable to continental jurists, because of the suggestion contained therein that the rules of the conflict of laws have their foundation, not in considerations of law and justice but of self-interest and courtesy to other states. Meili has said of comity that it had prepared a " juridical blind alley " ${ }^{86}$ for our subject, and that it blocked the way to its future development. According to Gutzwiller, a system of the conflict of laws based upon "comity" is "based upon sand ".87 Bustamante says that comity is based on such ideas as interest, courtesy, and reciprocity, and that "the name of science cannot be given to them, nor even a practical and useful system be based thereon." 88

The objection that " comity" implies self-interest, convenience, and utility is in itself without force, for the positive rules of the conflict of laws of all foreign systems rest upon such considera-

82 STORY, op. cit. supra note $\mathrm{I} 3, \S \mathrm{I} 8$.

83 Id. § 20.

84 Id. $\$ 23$.

85 Id. $\S 35$.

86 Ein Specimen aus der holländischen Schule des internationalen Privatrechts (Ulricus Huber 1636-I694) (I898) 8 ZeITSCHRIFT Für INTERNationales PrIVATUND STRAFRECHT I89, Igo.

87 Internationalprivatrecht, I STAMMLER's DAS GESAMTE DEUTSCHE RECHT

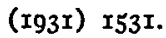

88 I Tratado de Derecho Internactonat Privado (I896) 456; see also I Bustamante, Derectio Internactonal Privado (I93I) 22. 
tions. For example, the choice between the law of domicil and that of nationality and the notions of " public policy" are clearly determined by them. Nor would, in the eyes of most continental jurists, the objection to the Anglo-American point of view be removed by the mere elimination of the word "comity" from its juristic terminology. Following Savigny, they insist upon the necessity of some international foundation for the rules of the conflict of laws. They regard the rules of the conflict of laws as imposed by some superior or outside power - be it that of international law, or of a common consciousness which is binding in the nature of things. Between this view and the Anglo-American law there is an irreconcilable gulf. Anglo-American law does not admit the concept of law entertained by the above writers, which has no reference to physical force. It insists, therefore, that in the present organization of the world the rules of the conflict of laws are not enforced by any outside or superior authority, but are voluntarily accepted by each sovereign state. The very fact of sovereignty precludes the notion that foreign law can have any force or validity within the state except with the permission of the territorial sovereign.

Story's views on the subject of comity have been attacked in the United States, so far as they have reference to the laws of the different states of this country. The contention has been made that the courts of one state should be under a constitutional obligation to recognize rights created by the law of a sister state, and that Story's notion of comity has prevented the adoption of this view by the Supreme Court of the United States. ${ }^{89}$ The allegation is that under the comity doctrine the courts of one state have declined to give effect to causes of action that arose in a sister state. The Supreme Court has recognized in the past the power of the courts of the individual states to decline to enforce causes of action of a sister state on grounds of public policy, but it is free at any time to reverse this position by invoking the due process clause or the full faith and credit clause of the Federal Constitution. If a distinction is to be made between the power of courts to enforce causes of action that have arisen in a foreign country and those that have arisen in a sister state, it would seem that the

89 Beach, Uniform Interstate Enforcement of Vested Rights (IgI8) 27 YaLE L. J. $656,657-58$. 
proper way of attaining the end would be by invoking constitutional provisions and not by an attack upon the comity theory in general. So far as the rules of the conflict of laws are concerned, apart from constitutional obligations, it is perfectly clear today that they are adopted by our courts in the same manner as are rules of domestic law. Since comity in the sense of courtesy to other nations is not a factor entering into the judicial process, it would be well if the use of the term were abandoned.

Serious issue may be taken with Story's territorial theory of Anglo-American law. The assertion that "no state or nation can by its own laws directly affect or bind property out of its own territory, or bind persons not resident therein " is, to say the least, misleading. " "Much of the confusion in Anglo-American legal thinking", says Professor Cook, "goes back to Story's treatise." 91 A detailed criticism, however, of Story's views in this regard would be out of place in a commemorative article on the occasion of the one hundredth anniversary of his Commentaries. Many new schools of thought have arisen since the time of Story, and in the light of these changes no general statement made a century ago concerning the nature of sovereignty, law, or rights will bear the test of critical examination today. There are even now great differences of view regarding the most elementary and fundamental notions in the conflict of laws. Continental thought still differs radically from Anglo-American, and no agreement exists among the writers of any country. Other criticisms of Story's treatise, to the effect that it avoids any statement of general principle, ${ }^{02}$ that it contains no attempt at historical development of the subject, ${ }^{93}$ and that it is "one of the least scientific $",{ }^{94}$ because of its indiscriminate use of foreign authors, may be ignored likewise, in view of the general objective of this article.

No doubt, the great vogue since the days of Savigny of $a$ priori writings on the conflict of laws hid for a time on the continent the

20 See Lorenzen, Territoriality, Public Policy and the Confict of Laws (I924) 33 YALE L. J. 736, 737; Cook, The Jurisdiction of Sovereign States and the Conflict of Laws (I93I) 3 I CoL. L. REv. 368.

91 The Logical and Legal Bases of the Conflict of Laws (1924) 33 YaLE L. J. 457,483 .

$92 \mathrm{BAR}$, op. cit. supra note 66 , at 46 .

93 Id. at 47 .

94 HARRISON, loc. cit. supra note 2. 
true merits of Story's Commentaries. In recent years, however, a change has come about in continental thinking, for the exclusive use of the theoretical method has been found insufficient and a more realistic approach in the study of the conflict of laws found to be indispensable. As a result, Story is honored once more as the first and foremost representative of the practical method. One of the leading German writers, speaking of Story's influence upon the development of the conflict of laws, says that through his influence upon Foelix, Savigny, and Bar he has given Europe "a sound and equitable conception of the conflict of laws ". ${ }^{95}$ This is the highest praise that could be bestowed upon any author. In the United States and England, Story is revered today as the father of the conflict of laws. In this one hundredth anniversary year of the publication of his Commentaries, the rest of the world joins the Anglo-American in rendering homage to the great American jurist, and to acclaim him one of the leading personalities of all time in the field of the conflict of laws.

Ernest G. Lorenzen.

YALE SchOOL OF LAW.

95 Gutzwiller, 29 RecueIl DES CouRS, ACAD. DE DR. INT. (I929) 34I, 35 I. 